This is the uncorrected version of the article published subsequently as:

Nentwich, Julia C.; Kelan, Elisabeth (2014). Towards a topology of 'doing gender': An analysis of empirical research and its challenges. In: Gender, Work and Organization 21 Nr. 2, p. 121-134, DOI:10.1111/gwao.12025.

\title{
Towards a topology of 'doing gender': An analysis of empirical research and its challenges
}

\section{Nentwich Julia and Kelan Elisabeth}

\begin{abstract}
'Doing gender' is a much used term in research on gender, work and organizations. However translating theoretical insight into empirical research is often a challenging endeavour. A lack of clarity in regards to the conceptionalisation and operationalization of key terms in turn often limits the theoretical and empirical purchase of a concept. The aim of this article is therefore to provide a systematisation of empirical approaches to 'doing gender'. This systematisation leads to a topology of five themes that is derived from empirical research in the field. The five themes identified are structures, hierarchies, identity, flexibility and context specificity, and gradual relevance/subversion. Each theme explores a different facet of 'doing gender'. This topology helps empirical researchers to be more specific about which aspects of 'doing gender' they are referring to. This in turn can help to unfold the theoretical potential of the concept of 'doing gender'.
\end{abstract}

\section{Introduction}

'Doing gender' is now a widely used concept for theorizing and researching gender in organizational studies. By looking at 'doing gender' the focus shifts away from treating men and women as self-evident categories in academic research towards seeing gender as a social 
practice. Going way back to West \& Zimmerman's seminal article published in 1987, their "original idea has taken on a life of its own" (West \& Zimmerman, 2009, p. 113), also in research on gender, work and organization. Besides the early ethnomethodological take on 'doing gender', more recent studies have started to elaborate on Butler's notion of performativity and theorize gender as something that is 'said and done' (Martin, 2003), a situated social practice (Butler, 1990; 1993; 2004). Many articles today discuss both West and Zimmerman as well as Butler in relation to 'doing gender' (Mavin \& Grandy, 2011), indicating that both theories have gained prominence (McDonald, 2012).

However, despite these theoretical developments and obvious heterogeneity in theoretical referencing, most empirical studies seem to define the term quite similar, thereby mainly echoing Simone de Beauvoir's famous quote 'one is not born, but becomes a woman.' This fairly general interpretation of 'doing gender' is what Wickes \& Emmison (2007) have called 'ceremonial' referencing. In their analysis of 149 publications on 'doing gender' in the ethnomethodological tradition, they found almost $73 \%$ of the publications to only quote the concept for matters of positioning the authors or the text as gender researcher(s), but do not necessarily take up the concept in neither the conceptual discussion nor the research methodology. 'Doing gender' is here appropriated "as a way of grounding, legitimating or validating their own research findings" (Wickes \& Emmison, 2007, p. 322) without engaging and developing the theoretical underpinning of the concept.

Although we would agree with Wickes \& Emmison that doing gender as a concept is often cited for purposes of positioning and legitimating and hence used in ceremonial ways, we suggest a different interpretation of this finding. Concepts travel (Czarniawska \& Sevón, 2005); they are translated and appropriated in different contexts and thereby changed, if they meet the needs of a community at a certain point in time. Talking about doing gender, the concept serves as a wildcard for the linguistic and practice turn in gender studies that had evolved throughout the 1990s. Hence, although quoting the concept of doing gender might be 
a ceremonial act in many papers intended to flag the author's position within a specific community of researching gender, it still develops some theoretical understanding of what doing gender means and how it is translated into an empirical research design. Our perspective is hence not about theoretical orthodoxy, but investigating the many uses and empirical questions that research labelling itself as contributing to doing gender is making.

In the following article, we analyse how empirical studies investigated the doing of gender in the context of work and organization studies. This empirical take on the question, how doing gender has been conceptualized and operationalized in empirical studies allows us to depict in what ways the concept has contributed to our knowledge of gender at work and in organizations, as well as the specific challenges empirical research on doing gender is facing.

The article starts with a short review of the theoretical debate on doing gender, highlighting the crucial changes in how gender has been theorized in both the work of West and Zimmerman and Butler. Second, we outline how we analysed the empirical articles in order to develop a 'topology' of crucial themes for doing gender research. Third, we discuss the empirical contributions according to this topology, thereby contributing a systematization of how researchers in the field of gender, work and organization have empirically analysed doing gender as well as the challenges their studies are facing. Forth, we offer a short conclusion discussing the major challenges of this endeavour as well as possible ways forward. Our analysis will enable researchers to conceptualize their studies in a more precise way, thereby also enhancing the theoretical development of the concept.

\section{Conceptualising gender as a doing}

The expression 'doing gender' goes back to Garfinkel's work on the intersexual Agnes in 1967, and this expression has been refined and developed over the years. While a first conceptualisation of the social construction of gender identity was put forward in West \& Zimmerman's ethnomethodological foundation in 1987, Butler's work on the performativity 
and materiality of gender developed a poststructuralist notion of gendered subjectivity. With that gender identity became a more fluid and flexible concept, and the analysis of 'doing gender' an analysis of the gendered practices that shows how both stability and instability of how gender identity is 'done' as well as 'undone'.

One central point of ethnomethodological analysis that West and Zimmerman (1987) put forward is to show how gender is created in the situation rather than existing a priori. They thereby emphasize the importance of interaction for an understanding of gender identity as well as inequality. Doing gender is conceptualised as a routine accomplishment in social interactions. In order to be categorised as a man or a woman interactional work has to be done. This work is under constant risk of gender assessment as one is accountable for 'doing gender'. According to West and Zimmerman, one can never not do gender, because it is such an integral part of individual identity as well as societal structures. West and Zimmerman thereby stress the importance of the ethnomethodological concept of omnirelevance: gender is relevant in every social situation. Furthermore, gender is seen as an important part of societal structures and informing societal hierarchies and power systems. Hence, societal structures and hierarchies as well as inequalities are important to explain how gender identity can be done in a certain interaction.

A second theoretical influence of gender as a doing derives from the work of Judith Butler (1990, 1993, 2004), drawing mainly on poststructuralist theories. In her critique of the feminist construction of the stable subject 'woman', Butler develops a critical genealogy of gender categories in which she explores why gender identity is perceived as something stable even though it is enacted in the situation. She "introduces a concept of decentred subjectivity in which the subject is open-ended and indeterminate except when it is fixed in place by culturally constituted gendered practices." (Gherardi, 2005, p. 222). Hence, the fluidity and flexibility of identity constructions as well as its context specificity have gained importance. 
A central concept in Butler's work is performativity. There is much debate about what performativity means (Brickell, 2005; Lloyd, 1999; McIlvenny, 2002), but one may summarise it as the process through which gendered subjects are constituted by regulatory notions within a heterosexual matrix. For Butler subjects are constructed by the positions the discourse allows. Following speech act theory, some of these positions speak to or 'interpellate' persons and in orienting toward these discourses subjects are reinstated. For instance Butler refers to 'girling the girl' as a gendering moment. When a baby is born the label 'girl' or 'boy' is assigned to the baby and this calls into being the baby as a gendered being. Thus the baby girl is interpellated; later in life, and in responding to this term the person creates herself as a woman. In citing these subject positions people render themselves legible but at the same time what is legible as a human being is defined within fairly narrow limits. Which subjects can be formed depends on gender norms, which are restrictive and heterosexual.

Both perspectives of theorizing gender as a social practice conceptualise gender identity as an ongoing activity or a 'doing' within everyday life. However, ethnomethodologically grounded studies tend to treat gender as omnirelevant and reproduced in any situation. Hence, they are rather focusing on the persistence of inequalities (Deutsch, 2007), while studies focusing on the performative construction of gendered identity tend to focus on its situated and fluid character and hence questions of change (Butler, 2004; Poggio, 2006). While West and Zimmerman would analyse fine grained naturally occurring interactions, Butler's conception of 'doing gender' focuses more on how gender is performed to real and imagined audiences. As a matter of fact, although both traditions developed notions of 'undoing gender', again, those concepts tackle different issues (Kelan, 2010). 'Undoing gender' in an ethnomethodological understanding challenges the general assumption that gender is 'omnirelevant', meaning that it is relevant in every situation and that we "cannot escape gender" (Hirschauer, 1994; 2001). It points to situations where gender 
might be not as relevant or even irrelevant for the sense-making process. These latter interactions might become sites of resistance where gender can be undone (Deutsch, 2007).

The ethnomethodological understanding defines 'undoing as a reduction of gender differences and is hence interested in the gradual relevance of 'doing gender'. Butler's understanding of doing gender is slightly different. It focuses on the question of how alternative performances might make it possible "to change the dominant gender order and the binary understanding of masculinity and femininity" (Poggio, 2006, p. 227). Therefore, studies relying on Butler's theorising tend to tackle possibilities of undoing gender from a perspective of subverting subject positions (Gherardi \& Poggio, 2007). Aspects of gradual relevance and subversion have gained importance when researching the social practices of doing gender (Linstead \& Brewis, 2004; Martin, 2003, 2006; Nentwich, 2008; Poggio, 2006).

This brief review of the theoretical and partly historical debates around the notion of 'doing gender' highlights that there have been important changes in how gender identity is theorized. While gender identity has been theorized as something that is done in a specific situation and no longer an attribute of the individual, recent developments highlighted the performative character of becoming a gendered subject. As a matter of fact, gender identity seems to be a much more flexible concept as the meaning of masculinity and femininity seems to shift between contexts, might be irrelevant or downplayed in a situation, or subverted in another.

Theorizing gender identity as something that is said and done resulted in major challenges for empirical studies: If gender is not seen as a fixed category that can be defined prior to the research conducted, the actual practices of constructing or performing that identity have to be analysed. Instead of taking women and men at face value, researchers have to be careful not to reify everyday taken for granted assumptions about gender but to critically investigate how they actually came into being. 
Theoretically, being a man or a woman should be the outcome of a process rather than the starting point. This is however easier said than done. For instance, Fournier \& Smith (2006) criticize Metcalfe and Linstead (2003) for claiming to undertake a "post-structuralist feminist reading" stressing "plurality rather than unity" (Fournier \& Smith, 2006, p. 144, cf. Metcalfe and Linstead, 2003, p. 98) while at the same time linking 'soft managerial practices' to the 'feminine' and teamwork, theorised as privileging control and performance, to the 'masculine'. Fournier \& Smith (2006, p. 144) state that at this point "essentialism seems to relentlessly creep back.” The result is a form of 'clichéd constructivism' (Brubaker \& Cooper, 2000) "relying on standard signifiers and theoretical gestures towards the fluidity of gendered identity" (Fournier \& Smith, 2006), which seem to be difficult to realize in empirical projects.

These questions are not new and other scholars have tried to explore such issues in the context of masculinity (MacInnes, 1998). Our aim in this article is hence to provide a systematization of how researchers in the field of gender, work and organization have empirically analysed doing gender, how this resulted in different conceptualizations of gender identity and to discuss the possible challenges and pitfalls of empirical studies.

\section{'Doing gender' in empirical studies: A critical analysis}

After briefly reviewing some theoretical debates and developments of the concept of 'doing gender', we now focus on the question of how researchers in the field of gender, work and organisation have empirically analysed 'doing gender'. In order to shed light on the question, how 'doing gender' was analysed in empirical studies, we first collected literature on 'doing gender' in an organizational and work context through overviews (Ashcraft, 2006; Bruni, Gherardi \& Poggio, 2005; Gherardi, 1995; Gildemeister \& Wetterer, 1992), conceptual texts (Martin, 2003), and highly relevant and often cited texts (Gherardi, 1995; Hall, 1993; Kondo, 1990; Leidner, 1991; Williams, 1995). We also searched databases using the search term 'doing gender'. Our objective was not to provide an exhausting overview of the available 
literature as for instance to be found in Wickes \& Emmison's analysis (2007), but to discuss theoretically-driven aspects of employing the concept(s) of doing gender in empirical research in the field of gender, work and organization.

For this reason we deliberately restricted our analysis to articles that first of all are based on empirically research; second, explicitly draw on the notion of 'doing gender', and third apply this concept to a work and/or organizational context. We selected articles published in international journals rather than books, as journal articles tend to present underlying theories and applications concisely. All articles are written in English and appeared in North American or British academic journals, covering the period between 1991 and 2009. This selection resulted in a core body of 17 texts, which were analysed by both authors independently exploring four questions: (1) What are the article's aims and how are these aims addressed? (2) How is 'doing gender' conceptualised? (3) How is 'doing gender' and, as a consequence, 'gender identity', operationalised in empirical studies? (4) To what results do these questions lead? During a series of discussions between the two authors, we structured the empirical findings according to the five central themes highly relevant for the understanding of 'doing gender' (see Table 1): (1) Structures, (2) hierarchies, (3) identity, (4) flexibility and context specificity, and (5) gradual relevance and subversion. However, this topology does not suggest that studies fit easily in one of the themes. Depending on their research focus, one study might tackle more than one theme. Therefore, we will discuss different aspects of one study under several themes to highlight some of the different angles used.

\begin{tabular}{|l|l|}
\hline Relevant themes for 'doing & How studies have addressed these aspects \\
gender' research & - Hall (1993); construction of differences between 'waitering' and \\
'waitressing' through formal elements. \\
Structures
\end{tabular}




\begin{tabular}{|c|c|}
\hline & $\begin{array}{l}\text { differently through reference of the job's gender. } \\
\text { - Murray (1996); men in childcare, show difficulties of constructing } \\
\text { masculinity resulting from the femininity of the job. }\end{array}$ \\
\hline Hierarchies & $\begin{array}{l}\text { - Hall; waitering is valued higher than waitressing. } \\
\text { - Korjavärvi (1998); men's style of doing work is more in line with the } \\
\text { efficiency goals and valued higher than women's styles. }\end{array}$ \\
\hline Identity & $\begin{array}{l}\text { - Murray and Hall: interactional strategies and } \\
\text { - Cross \& Bagilhole (2002); discursive strategies through which men are } \\
\text { constructing a masculine identity in female dominated professions. } \\
\text { - Katila \& Meriläinen (1999); conflicts arising when women have to } \\
\text { construct professional identities in male dominated academia. } \\
\text { - Pierce (1996); women having to engage in male connotated behaviour in } \\
\text { order to be 'good'. } \\
\text { - Powell and co-authors (2008); 'coping strategies' for handling female } \\
\text { identity in engineering. }\end{array}$ \\
\hline Flexible and context specific & $\begin{array}{l}\text { - Leidner; similar activities are gendered differently depending on who does } \\
\text { it. } \\
\text { - Pierce; how emotional labour can also be constructed as something } \\
\text { masculine in the context of litigation. } \\
\text { - Martin (2001); looking at women's interpretations of men's behaviour } \\
\text { showing that there are many ways of doing masculinity } \\
\text { - Pilgeram (2008); different norms in different spaces }\end{array}$ \\
\hline $\begin{array}{l}\text { Gradually } \\
\text { subverted }\end{array}$ & $\begin{array}{l}\text { Gherardi (1994, 1996), Gherardi \& Poggio (2004) and Bruni, Gherardi \& } \\
\text { Poggio (2004); how the symbolic gender order is enacted in one situation } \\
\text { and denied in another } \\
\text { Johannson (1998); different interpretations of gender in a specific situation } \\
\text { lead to vague and not so clear cut lines between women and men } \\
\text { Hall, Hockey \& Robinson (2007): Gender, here masculinity, can be enacted } \\
\text { differently. They emphasize the subject's agency within normative } \\
\text { constraints. }\end{array}$ \\
\hline
\end{tabular}




\begin{tabular}{|l|l|}
\hline & $\begin{array}{l}\text { Pullen and Simpson (2009): masculinity can be undone by drawing on } \\
\text { aspects of the job usually seen as female-connotated (caring). }\end{array}$ \\
\hline
\end{tabular}

TABLE 1: 'Doing gender' in empirical studies

\section{Doing gender as 'doing structures'}

A first theme in the research on 'doing gender' are gendered structures. Gendered structures are embedded in jobs and enable the construction of gender identity. Furthermore, the gender of the job "rubs off on the people who do them" (Cockburn, 1985, p. 169). In order to fulfil the expectations attached to a job, or in other words to do the job properly, the employee often has to enact a certain gender identity according to these structures. Gendered structures (re)inforce gendered interactions. An example is flight attendants, a job which requires a ‘doing of femininity' (Brewis \& Linstead, 2000; Hochschild, 1983; Tyler \& Abbott, 1998). This involves being friendly to passengers and caring for them, engaging in behaviour that is closely linked with femininity in society. Thus a job requires a performance which is often cross-referenced with gender and which entails doing gender identity in a certain way.

A study focusing on structures and doing gender was conducted by Hall (1993) on restaurant employees. Adopting ethnographic and quantitative methods she looked at how the differentiation between 'waitressing' and 'waitering' is created. Whereas 'waitering' is defined as something men do, 'waitressing' is seen as 'typical women's work' because women perform it and because the work activities are considered 'feminine' (Hall, 1993, p. 329). Although serving tables is the job requirement for both professions, people doing this work are often distinguished through formal elements like uniforms. Through uniforms table servers become 'waiters' and 'waitresses' and this is a way through which gender 'rubs off' and difference is interactively constructed. Here, structures lead to doing gender through the display of the job's gender, containing scripts for the interactional doing of gender identity such as wearing a certain uniform. 
In a study on scripts in interactive service work, Leidner (1991) found that similar interactions are gendered completely differently in different jobs. People working in fast food restaurants and selling insurance follow similar scripts of service work. For instance, in both types of work, Leidner found that employees commonly had to learn pre-formulated phrases to use when interacting with customers. Although the actual customer interaction was similar, in this case fast food work was defined as feminine and selling insurance was constructed as masculine. Here, the gender of the task enabled a specific doing of gender identity: masculinity or femininity. In their studies, both Leidner and Hall show how individuals doing a job are doing gender at the same time. Interestingly, the gender of the job often has less to do with the tasks themselves and more to do with the gender ascribed to the job and performed by workers. Both Leidner and Hall assume that women working in a job perceived as 'feminine' and men working in a job seen as 'masculine' are enacting femininity and masculinity respectively.

Here, gender identity is done through engaging in a job that is either 'masculine' or 'feminine'. However, what happens if women work in male-dominated fields or men in female-dominated fields? Studies on men and women in non-traditional occupations have explored this question (Bagilhole \& Cross, 2006; Cameron, 2001; Cross \& Bagilhole, 2002; Powell, Bagilhole \& Dainty, 2008; Williams, 1989, 1993, 1995). For example, Murray (1996) shows that a mismatch between the gender identity of the person and the job's gender is no challenge to the stereotypical gender assignment of the job but raises difficulties for the individuals at work. She looks at men working in a job not associated with men: childcare. Her focus is on how childcare is gendered as feminine regardless of whether a woman or a man is performing the job. She points out that the association of this work with 'femininity' means that men can never meet the standards that are expected. Often, men can only engage in certain tasks and are recommitted to them by 'boundary work'. At the same time they are often praised for doing their job well as men are not expected to do a feminine-connoted task 
well. Through engaging in tasks requiring them to do what is constructed as 'femininity', men are perceived as violating the normative expectations of masculinity. It is thus difficult for men working in childcare to pass as 'real men'. This is because they are at danger of being gender inauthentic when engaging in a 'female job'. This example shows clearly how gendered assumptions about jobs lead to a specific form of 'doing femininity' or 'masculinity'.

All these studies explore practices of 'doing gender' in order to explain how occupations become gendered. Gender is part of the occupational or organisational structures and forces certain kinds of gendered interactions, either a 'doing of masculinity' or a 'doing of femininity'. In some cases, the gender of the job is inscribed in the definition of the occupation. In other cases, almost any aspect of the job might be constructed as gendered. The practice might come in the form of a gendered uniform (Hall, 1993) or engaging in a task ascribed stereotypically to being either masculine or feminine. However, what often remains unclear is how a job became gendered in the first place or how the tasks performed are said to be 'feminine' or 'masculine' (cf. Fournier \& Smith, 2006). The gender of the job is in some instances ascribed because of the number of men or women working in it; in other cases minority and majority relations are not even mentioned. In general, it is assumed that a job 'has' a certain gender as do the persons performing it. Here, one 'does' gender when doing the job and the gender of both the individual and the job are constructed while doing the job. However, what is described as a practice of 'doing structure' becomes a static and well established structure when translated to the research design. Some critical reflection on the dualisms applied by the research itself might be necessary. Future research should at least reflect why the occupation or field researched is seen as a 'female' or a 'masculine' dominated field and focus on the consequences for the doing of gender respectively.

\section{Doing Gender as 'doing hierarchies'}


The second theme we want to emphasize is gendered hierarchies. Although it is rather similar to the first theme of structures, we included hierarchies as a separate focus because it helps to see the asymmetry of gender hierarchies and also sheds light on some different effects of doing gender as well as empirical challenges. 'Doing gender' here means 'doing of hierarchies' which eventually leads to inequality. Research focusing on hierarchies looks at the symbolism attached to certain activities in which the 'masculine' is seen as superior to the 'feminine'. Whatever is gendered 'feminine' tends to be devalued; whatever is gendered 'masculine' receives higher status, and is perceived as more professional and as representing competence (Heilman, 2001; Ridgeway, 1997). Hence, due to the hierarchy, 'doing masculinity' and 'doing femininity' are different practices with different results.

In comparing 'waitering' with 'waitressing', Hall (1993) showed that the term 'waiter' and the task of 'waitering' are valued more highly than 'waitress' and 'waitressing'. Even women engaging in the task of 'waitering' can obtain a higher status compared to their female colleagues who are doing 'waitressing.' In a study on an employment office Korjavärvi (1998) highlighted similar practices. Here women and men used different styles to get their work done. While women focussed on helping clients and interacting with them, men focussed on a quick turnover of people. At the same time men's style of doing work was more in line with the efficiency goals of the organisation and as such valued more highly than the women's style. 'Doing gender' is linked to activating symbolic hierarchies and in these symbolic hierarchies the 'masculine' is valued over the 'feminine'.

In these studies, the doing of gender is analysed as practices of subordination and domination. Again, the logic of the hierarchy is associated with masculinity and femininity. Gender is done through drawing on the symbolic hierarchies and re-establishing them when 'doing masculinity' or 'femininity.' Whereas the subordinate position in this logic is 'femininity', 'masculinity' becomes the dominant. As Hall's research shows, the sex category seems less important compared to the gendered job enacted in the doing of hierarchies: 
individual women can obtain a higher status when practicing 'waitering' instead of 'waitressing.'

However, the analogy between femininity and masculinity and subordination and domination seems all too often a taken for granted in research about 'doing gender'. Again, the research rarely explores how the hierarchical order is established or interpreted by the men and women researched (see also Fournier \& Smith, 2006; Linstead \& Brewis, 2004). Investigating whether this hierarchy is always re-established or if other forms of hierarchical gender relations are possible in some contexts might be a worthwhile research question. Are non-hierarchical gender relations possible at all?

Furthermore, as the masculine is valued more highly than the feminine, 'doing masculinity' and 'doing femininity' should be analysed as rather different practices. For instance, in a context associated with 'masculinity', 'femininity' might always be at risk of being marginalised and undervalued. However, the same is not true for masculinity in a feminine context. Hence, 'doing masculinity' and 'doing femininity' cannot easily be subsumed under a generic heading of 'doing gender' but should rather be analysed as different 'doings' (Martin, 2001; 2004).

\section{Doing gender as 'doing identity'}

Gender identity is as discussed earlier central for 'doing gender.' We have already touched on gender identities in the first two categories. We discussed how the job one does is integrally linked to one's gender identity. It is commonly assumed that there is a link between 'doing gender at work' and 'doing gender identity'. In other words, a feminine gender identity is constructed through working in a feminine-connoted job or engaging in a feminine-connoted task. However, the relationship is more complicated than this, and the studies we described earlier are very explicit about this. For instance, Murray (1996), Williams (1989) and also Hall (1993) have shown how men construct their work as masculine to deal with a possible 
conflict in a so-called gender-atypical profession. For instance, men in nursing more often engage in physical tasks such as lifting and moving patients (Williams, 1989, p. 142). Men working in childcare were shown to develop routines in which men avoided 'napping' the children or having them on their laps. This was interpreted as belonging to the "nurturing responsibility' associated with women. Also, the parents regarded these men engaging in nurturing as highly suspicious (Murray, 1996, p. 377ff). Similarly, Cross and Bagilhole (2002) conducted an interview study with men working in several atypical professions. They highlight strategies through which men are able to construct masculine identities despite 'doing femininity' while at work. These men do 'boundary work' and distance themselves from the ways that women do the job. This distancing enables them to construct masculine gender identities.

As gender is constructed hierarchically, the consequences for identity construction in gender-atypical contexts are different for women and men. Powell and co-authors (2008) show how women in engineering use several 'coping strategies' to handle their identity in a male-dominated field. These women engineers, however, did not distance themselves from what could be labelled as 'male engineering'; instead, they denied their femininity. Also Katila and Meriläinen (1999) explored how women create their professional identities in the male-dominated world of academia. They show how, in the professional discourse at a university, the 'masculine' is taken as the norm or ideal. While men are described as successful and professional researchers, women are called 'girls', 'seducers' or simply 'beautiful' (Katila and Meriläinen, 1999, p. 171). In a context of such strong gendersegregating discourses that describe women as lacking exactly the criteria they need to be professional researchers, it becomes difficult for women to construct a professional identity. Women constructing a feminine gender identity would have to engage in behaviour that shows them as being more private, invisible and submissive. Yet what is required is 'doing masculinity' by being aggressive. Constructing oneself as a professional researcher and as a 
woman appears to be a contradiction in terms. In a similar way the female litigators investigated by Pierce (1996) experienced a conflict when they had to engage in emotional labour - which is here associated with masculinity - in order to be perceived as 'good litigators'.

Focusing on the construction of gender identity while doing the job makes 'doing gender' even more complicated. The issue is not only that structures require the individual to 'do gender', but also that 'doing gender' does not necessarily lead to a certain gender identity. Gender identities can be constructed through stressing or downplaying specific aspects of the job.

While the concept of 'doing gender' assumes that people achieve a certain identity through 'doing gender', the studies analysed here, however, rarely focus on the process of identity construction within a specific situation. Very often the construction of gender is analysed separately from the process of 'doing identity', or, in Hall's words, it is assumed that "workers 'bring' gender to their jobs" and not that they "“do gender', performing their jobs in certain ways because their jobs are structured to demand gender displays" (Hall, 1993, p. 331). Other studies assume that gender identity is something developed in early childhood (Pierce, 1995) and is a stable and unchangeable category (Leidner, 1991). For instance, in research on men in non-traditional occupations these men are already men and only bolster their masculine identity through rejecting certain feminine-connoted aspects of their work. Through this analysis, essentialist understandings of gender are reified (Fournier \& Smith, 2006).

Future studies should rather aim at investigating how 'being a man' or 'being a woman' is achieved as a social practice and not as a given fact that existed prior to the research. Exploring the consequences of fluid identity constructions further, the following two themes shed some lights on how research has tackled this. 


\section{Doing gender as flexible and context specific}

The concept and application of 'doing gender' showed so far, that the asymmetry of gender relations is repeated and reproduced through referencing a fairly stable binary of 'femininity' and 'masculinity'. However, it also makes apparent that what is defined as 'masculine' and 'feminine' is flexible across time and space (Borgerson \& Rehn, 2004; Linstead \& Brewis, 2004). In the study quoted previously, Leidner (1991) shows how similar activities are gendered differently depending on who performs them. Another example is the study on litigators by Pierce (1996), who shows that emotional labour, which is often described as something feminine in nurses or flight attendants (Hochschild, 1983), is seen in litigation as something masculine. Being a good litigator means performing specific forms of emotional labour such as 'strategic friendliness' and 'intimidation' that are associated with masculinity.

In another study, Pilgeram (2007) shows how female farmers do gender differently in different spaces of a livestock auction. While the stock auction in general is historically and structurally a male-dominated field, different norms are in place in the more private spaces of the corrals compared to the public space of the auction house. While "women in the public space were expected to be nurturing and clerical, for the women in the corrals there is an expectation of toughness from both their male and female colleagues" (Pilgeram, 2008, p. 589). These examples highlight the importance of exploring in detail how something is gendered in a specific profession, space or context rather than assuming that certain interactions are a 'doing masculinity' or 'femininity'. The concepts of 'doing gender' applied here highlights the flexibility through which gender identity can be done. This theme urges us to look at local definitions of gender and different masculinities and femininities.

The relevance of who interprets 'doing gender' is explored by Martin (2001). Her interest is in how 'doing masculinity' happens in organisations. Instead of observing and interpreting herself, she interviewed women on their experiences of men at work and their interpretations of masculine behaviour at work. She adopts a feminist standpoint perspective 
(Hartsock, 1983) in which women provide a clearer account of hegemonic practices as they are said not to be immersed in these practices. Thus, Martin is able to show some of the different ways that masculinity is enacted in a work context. This challenges the idea that there is only one way in which masculinity can be done (cf. Frenkel, 2008). We thus see the importance of an audience evaluating 'doing gender' and what counts as 'masculinity' or 'femininity' in a given situation.

Because what is defined as masculine and feminine shifts with the respective context, studies developing this theme have highlighted ways to show the flexibility that is possible in defining gender. One cannot assume, however, that certain characteristics which are defined as feminine in the wider society will also be defined as feminine in a managerial context (Kelan, 2008). It has, for instance, been shown that the 'ideal worker' in technical work needs to display social and technical competence. While social competence is gendered as feminine in the wider society and technical workers draw on these discourses to argue why more women should be in technical work, the general ideal technical worker is presented as strictly gender neutral. In fact, this assumed gender neutrality often means a disguised masculinity (Acker, 1990; Benschop \& Dooreward, 1998). What is defined as 'masculine' and 'feminine' in which context might be different and might also shift between contexts. If 'doing gender' is seen as flexible, the respective context and its empirical analysis gains importance.

\section{Gender as gradually relevant and subverted}

Drawing on the recent discussion on the possibilities on 'undoing gender', the fifth and final theme in 'doing gender' research stresses that gender identity is neither made relevant in each and every situation and can even be enacted as challenging and hence subvert the gender binary. Hence, research on gender should not only show where gender constructions are relevant; it should also reveal situations where gender is made less relevant (Deutsch, 2007; Hirschauer, 2001) or gender is enacted in challenging ways. In order to understand this point 
it is useful to turn to research by Gherardi $(1994,1996)$ and Gherardi and Poggio (2001). They analyse the organisational dynamics leading to the maintenance of the gender asymmetry in organisations. They do that through analysing women's narratives in maledominated employment areas (IT, engineering, and banking). Their focus is on how a gender asymmetry is created and how 'doing gender' is understood as a way in which gender identity is accentuated and ignored. For instance gender identity is accentuated when men hold a door open for women; through that behaviour the woman is constructed as woman. On the other hand, gender identity is ignored in other situations when women are given a collegial slap on the back - a practice more common among men. The woman is thus treated like 'one of the men' and gender is neglected or one could say enacted in a new way. In a similar vein Bruni, Gherardi and Poggio (2004, p. 423) show that the boundary between gender and entrepreneurship "is constantly blurred, traversed and denied, but then jointly reconstructed a posteriori." The process of citing a symbolic gender order when positioning oneself as an entrepreneur is not as clear and stable as the gender binary would suggest.

An example of how gender is done in subversive ways is provided by Johansson (1998). She studied how meaning is made around gender and was able to show how paradoxical this meaning making process is in an ethnographic study involving interviews and observations in a restructuring housing company. Like Bruni, Gherardi and Poggio (2004; Gherardi \& Poggio, 2001) she argues that 'doing gender' is understood as referring to dualistic gender stereotypes. For instance some men in her study complained about having to clean staircases after the reorganisation; that was seen as a women's task. However some men reacted more neutrally towards the work extension and accepted the new task as something they would do once in a while. Analysing her empirical material from the perspective of multiple possibilities, she illustrates that gender identities are not clear-cut but that different interpretations of masculinity and femininity are used in different situations. Gender identity 
is here cited in different and partly contradicting ways which theoretically might open the opportunity to 'doing gender' differently.

That gender identity can be done in normative as well as alternative ways is taken up in a study by Hall, Hockey and Robinson (2007) on 'doing masculinity'. They differentiate occupational status, age and also social class in analysing different masculinities relevant in fire fighting, hairdressing and real estate agents. They show that, depending on situational constraints and job-related objectives, men not only engage in practising different kinds of 'masculinity', but also what is commonly framed as 'femininity'. The study thereby highlights the subject's agency in 'doing gender' identity and opens up for further research in the possibilities and also boundaries of agency for 'doing gender'.

Pullen and Simpson (2009) investigate how 'masculinity' is done and 'femininity' appropriated in interviews with men. In contrast to Hall, Hockey and Robinson's study they chose to investigate men working in feminized occupations, as they were mainly interested in analysing how men negotiated being different from women and positioned as 'the Other'. They find that masculinity is both partially subverted and constructed by men doing femininity when, for instance, emphasizing the caring aspects of their jobs.

From these studies it becomes apparent that there is no easy way to understand gender but that one must pay attention to how the relevance of the gender binary changes from one situation to another. It is thus important to explore not only how gender identity is done, but also how it is 'undone'. Gender might be a relevant matrix in one situation, but not be taken up or done differently in another. Being a woman or being a man may be enacted quite differently in different contexts and might even be irrelevant in others. Furthermore, there is some flexibility in the normative assumptions on how gender should be done in a certain situation. Gender identity became a "practice of improvisation within a scene of constraint" (Butler, 2004, p. 1). As men can do 'femininity' and women 'masculinity' respectively, 
dominant or stereotypical understandings of 'masculinity' and 'femininity' might be subverted.

\section{Conceptual and Operational Challenges of 'Doing Gender'}

Research on 'doing gender' in a work context has elaborated on the social construction of gender. While the definitions of 'doing gender' provided in the studies sounded rather similar at first, our analysis showed that there are major differences in how 'doing gender' is conceptualized and operationalized. As Wickes \& Emmison (2007) have shown, research is by far not as coherent and monolithic as the common notion of 'doing gender' might suggest. 'Doing gender' is not only a heterogeneous concept, used within different theoretical traditions, but also a far more complex concept than often recognized.

On the basis of our analysis we have shown that research on 'doing gender' can be systematised based on five themes. First, 'doing gender' is linked to structures. Structures are seen as influencing how gender is done. Second, it is important to note that 'doing gender' also involves 'doing hierarchies' which normally means that the masculine is privileged over the feminine. Third, 'doing gender' means to explore how identities are constructed in a specific situation. While the earliest empirical studies we discussed mainly focused on interaction practices and the role of structures and hierarchy for constructing identity, more recent studies more and more adopt perspectives of decentred subjectivity as put forward by Butler's work. They focus on the ways people adopt and create subject positions and hence explore the context-specificity of 'doing gender' and gender identity. Finally, gender is not always made relevant in the same way and can even be done in a subverting way.

The analysis of 'doing gender' based on these five themes helped us to systematize relevant issues and point out important challenges for empirical studies analysing 'doing gender'. For instance, research on the relevance of occupational and organizational structures showed that structures are available as resources for 'doing' or 'undoing gender', but never 
ultimately define what can be done in a specific situation. Future research should be more specific about what is depicted as a feminized or a masculinised structure and rather focus on how they are made relevant in the situation analysed instead of taken its importance for the doing of gender for granted. Hence, research on doing gender analysing the relevance of gendered structures should move from this rather static conceptualization of structures to a perspective of 'doing structure' as well as, with regards to the next theme, issues of 'hierarchization.' Furthermore, the theme of hierarchies highlights the importance of differences between 'doing masculinity' and 'doing femininity' and hence masculine and feminine identities due to inequalities. Future research could explore these as different practices instead of subsuming them under the umbrella of 'doing gender'.

From the perspective of identity it was important to see that it is not necessarily men that do masculinity and women femininity respectively, but that both 'doings' are highly context specific. Research should focus on the identity practices within the situation analysed rather than assuming that somebody or something has a specific gender identity per se. Especially the themes of flexibility and context specificity as well as gradual relevance/subversion have shown that it is precisely these conflicting ways of 'doing gender' that would provide insight into how gender identity is done and how gender as an external reality is created while doing a job. As gender seems to be highly depending on the context and gender identity rather flexible, what is gendered as feminine in one context could be gendered masculine in another context.

Gender identity also marks the major conceptual turning point in the analysis of 'doing gender'. While studies relying on an ethnomethodological framework assume some stability in how gender identity is done or undone, Butler's notion of performativity highlights issues of fluidity and paradox. However, studies are not as clear-cut as could be assumed from a theoretical perspective. In both 'camps', empirical studies seem to struggle with how to analyse the actual 'doing' instead of only assuming or defining something as gendered, 
masculine or feminine respectively. It is in this sense, that we would see the notion of 'doing gender' as having only ceremonial consequences (Wickes \& Emmison, 2007).

This does not mean, however, that researchers have to select a 'pure' epistemological orientation such as either ethnomethodological interactionism or poststructural discourse approaches. In fact, research by Gherardi and co-authors (Gherardi \& Poggio, 2007; Bruni, Gherardi \& Poggio, 2005) as well as Kelan (2009) has shown that empirical studies on 'doing gender' can draw on a wealth of perspectives to explore how gender is done.

Disentangling these five different aspects of what 'doing gender' can be about strikes us as highly relevant for the future sophistication and theoretical development of the concept. The topology can provide some guidance and systematization. Starting with the relevant questions that we have put together in table 2, researchers designing a study on 'doing gender' can systematize their research questions, methodology and kind of knowledge they are gaining. Furthermore, being more precise about different themes that 'doing gender' research can investigate, this systematization also enables researchers to analyse possible interplays between the themes respectively.

\begin{tabular}{|l|l|}
\hline $\begin{array}{l}\text { Relevant themes for } \\
\text { 'doing gender' research }\end{array}$ & Relevant questions for research design and analysis \\
\hline Structures & - Why is it that we define the occupation or organization as \\
& gendered/masculine/feminine? \\
& - What kinds of social structures can we identify in our field of \\
& $\begin{array}{l}\text { research as well as in our data to legitimize our account of } \\
\text { something being gendered/masculine/feminine? (historical, } \\
\text { economical, organizational etc.) }\end{array}$ \\
\hline Hierarchies & $\begin{array}{l}\text { How are masculinity and femininity respectively made relevant? } \\
-\end{array}$ \\
& How are differences between masculinity and femininity created in \\
& an hierarchical way? \\
\hline
\end{tabular}




\begin{tabular}{|c|c|}
\hline Identity & $\begin{array}{l}\text { - How is the gender identity of individuals, but also tasks, professions } \\
\text { or occupations made relevant in the material? }\end{array}$ \\
\hline $\begin{array}{l}\text { Flexible and context } \\
\text { specific }\end{array}$ & $\begin{array}{l}\text { - What is the specific understanding of gender/masculinity/femininity } \\
\text { in this context? } \\
\text { - How does it differ across contexts in your research field? }\end{array}$ \\
\hline $\begin{array}{ll}\text { Gradually relevant and } \\
\text { subverted }\end{array}$ & - How are gender differences emphasized, downplayed or subverted? \\
\hline
\end{tabular}

TABLE 2: Relevant questions for research design and analysis

Using the topology for research design and developing analytic strategies will help to open the black box of what one can focus on when studying gender in the workplace from a 'doing gender' perspective. The topology should also not be seen as a finished project and one might well expect that new themes can emerge over time as the research in this area develops.

\section{Conclusion}

Our analysis has shown that theoretical debates on 'doing gender' seem to be very advanced and nuanced yet using these theoretical insights in empirical research remains a complex endeavour. While gender identity is theorized as flexible and context specific, gradually relevant and also subversive, all too often it is analyzed as a static construct, an attribute of individuals as women and men or of structures, such as masculine or feminine occupations or tasks. Our systematization of five central themes shed light on the challenging aspects of 'doing gender' research. If it is unclear what 'doing gender' means for different researchers and what they are focusing on, it is difficult to advance the field through increased theoretical sophistication. One of the key limitations of 'doing gender' as a theoretical and empirical concept is that it is often used in a "ceremonial" way and not analysed in accordance with its conceptual foundation. Being more specific about which aspects of 'doing gender' are 
focused on can hence help to develop theoretical sophistication. Our aim in the article was therefore to develop a topology that can guide future research in focusing and targeting their research on advancing the concept. Future research could benefit using this topology as a structure for operationalization and the construction of research designs. The resulting empirical research would help to develop 'doing gender' as an approach further. 


\section{References}

Acker, J. (1990). Hierarchies, jobs, bodies - a theory of gendered organizations. Gender \& Society, 4(2), 139-158.

Ashcraft, K. L. (2006). Back to work: Site/sights of difference in gender and organizational communication studies. In B. Dow \& J. T. Wood (Eds.), The Handbook of Gender and Communication (pp. 97-122). Newbury Park, CA: Sage.

Bagilhole, B. \& Cross, S. (2006). 'It never struck me as female': Investigating men's entry into female-dominated occupations. Journal of Gender Studies, 15(1).

Benschop, Y. \& Dooreward, H. (1998). Covered by equality: The gender subtext of organizations. Organisation Studies, 19(5), 787-805.

Borgerson, J. \& Rehn, A. (2004). General Economy and Productive Dualisms. Gender, Work \& Organization, 11(4), 455-474.

Brewis, J. \& Linstead, S. (2000). Sex, work and sex work - eroticizing organization. London: Routledge.

Brickell, C. (2005). Masculinities, Performativity, and Subversion: A Sociological Reappraisal. Men and Masculinities, 8(1), 24-43.

Brubaker, R. \& Cooper, F. (2000). Beyond "identity". Theory and Society, 29, 1-47.

Bruni, A., Gherardi, S. \& Poggio, B. (2004). Doing gender, doing entrepreneurship: An ethnographic account of intertwined practices. Gender, Work and Organization, 11(4), 407-429.

Bruni, A., Gherardi, S. \& Poggio, B. (2005). Gender and entrepreneurship: an ethnographic approach. London: Routledge.

Butler, J. (1990). Gender trouble: Feminism and the subversion of identity. New York: Routledge.

Butler, J. (1993). Bodies that matter: On the discursive limits of "sex". New York: Routledge.

Butler, J. (2004). Undoing gender. New York: Routledge. 
Cameron, C. (2001). Promise or problem? A review of the literature on men working in early childhood services. Gender, Work and Organization, 8(4), 430-453.

Cockburn, C. (1985). Machinery of dominance: Women, men and technical know-how. London: Pluto.

Cross, S. \& Bagilhole, B. (2002). Girls' jobs for the boys? Men, masculinity and nontraditional occupations. Gender, Work and Organization, 9(2), 204-226.

Czarniawska, B., \& Sevón, G. (2005). Global ideas: How ideas, objects and practices travel in the global economy. Malmö: Liber and Copenhagen Business School Press.

Deutsch, F. (2007). Undoing Gender. Gender \& Society, 21(1), 106-127.

Fournier, V. \& Smith, W. (2006). Scripting masculinity. Ephemera www.ephemeraweb.org, $6(2), 141-162$.

Frenkel, M. (2008). Gender identities in the Israeli Hi-Tech industry. Gender, Work and Organization, 15(4), 352-374.

Garfinkel, H. (1967). Studies in ethnomethodology. Englewood Cliffs, New Jersey: Prentice Hall.

Gherardi, S. (1994). The gender we think, the gender we do in our everyday organizational lives. Human Relations, 47(6), 591-610.

Gherardi, S. (1995). Gender, symbolism and organizational cultures. London: Sage.

Gherardi, S. (1996). Gendered organizational cultures: Narratives of women travellers in a male word. Gender, Work and Organization, 3(4), 187-201.

Gherardi, S. (2005). Feminist theory and organization theory. A dialogue on new bases. The Oxford Handbook of Organization Theory. Oxford University Press.

Gherardi, S. \& Poggio, B. (2001). Creating and recreating gender order in organizations. JWB, 36(3), 245-259.

Gherardi, S. \& Poggio, B. (2007). Gendertelling in organizations: Narratives from maledominated environments. Copenhagen: Liber. 
Gildemeister, R. \& Wetterer, A. (1992). Wie Geschlechter gemacht werden. Die soziale Konstruktion der Zweigeschlechtlichkeit und ihre Reifizierung in der Frauenforschung. In G.-A. Knapp \& A. Wetterer (Eds.), TraditionenBrüche. Entwicklungen Feministischer Theorie (pp. 201-253). Freiburg: Kore.

Hall, A., Hockey, J. \& Robinson, V. (2007). Occupational Cultures and the Embodiment of Masculinity: Hairdressing, Estate Agency and Firefighting. Gender, Work \& Organization, 14(6), 534-551.

Hall, E. J. (1993). Waitering/waitressing: engendering the work of table servers. Gender \& Society, 7(3), 329-346.

Hartsock, N. (1983). The Feminist Standpoint: Developing the Ground for a Specifically Feminist Historical Materialism. In S. Harding \& M. B. Hintikka (Eds.), Discovering Reality: Feminist Perspectives on Epistemology, Metaphysics, Methodology and Philosophy of Science. Dordrecht: Reidel.

Hartsock, N. (1987). The feminist standpoint: Developing the ground for a specifically feminist historical materialism. In S. Harding (Ed.), Feminism and Methodology (pp. 157-180). Milton Keynes: Open University Press.

Heilman, M. E. (2001). Description and prescription: How gender stereotypes prevent women's ascent up the organizational ladder. Journal of Social Issues, 57(4), 657-674.

Hirschauer, S. (1994). Die soziale Fortpflanzung der Zweigeschlechtlichkeit. Kölner Zeitschrift für Soziologie und Sozialpsychologie(Heft 4), 668-692.

Hirschauer, S. (2001). Das Vergessen des Geschlechts. Zur Praxeologie einer Kategorie sozialer Ordnung. In B. Heintz (Ed.), Geschlechtersoziologie (pp. 209-235). Wiesbaden: Westdeutscher Verlag.

Hochschild, A. R. (1983). The managed heart: Commercialization of human feeling. Berkeley: University of California Press. 
Johansson, U. (1998). The transformation of gendered work: dualistic stereotypes and paradoxical reality. Gender, Work and Organization, 5(1), 43-58.

Katila, S. \& Meriläinen, S. (1999). A serious researcher or just another nice girl? Doing gender in a male-dominated scientific community. Gender, Work and Organization, 6(3), 163-173.

Kelan, E. (2008). Emotions in a rational profession: The gendering of skills in ict work. Gender, Work \& Organization, 15(1), 49-71.

Kelan, E. (2009) Performing Gender at Work. Basingstoke: Palgrave.

Kelan, E.K. (2010) Gender Logic and (Un)doing Gender at Work. Gender, Work \& Organization, 17,2, 174-194.

Kondo, D. (1990). Crafting selves: Power, gender and discourses of identity in a Japanese workplace. Chicago: University of Chicago Press.

Korvajärvi, P. (1998). Reproducing gendered hierarchies in everyday work: contradictions in an employment office. Gender, Work and Organization, 5(1), 19-30.

Leidner, R. (1991). Serving hamburgers and selling insurance: gender, work and identity in interactive service jobs. Gender \& Society, 5(2), 154-177.

Linstead, A. \& Brewis, J. (2004). Editorial: Beyond Boundaries: Towards fluidity in theorizing and practice. Gender, Work and Organization, 11(4), 355-362.

Lloyd, M. (1999). Performativity, parody, politics. Theory, Culture \& Society, 16(2), 195213.

Martin, P. Y. (2001). Mobilizing masculinities: women's experiences of men at work. Organization, 8, 587-618.

Martin, P. Y. (2003). "Said and done" versus "saying and doing". Gendering practices, practicing gender at work. Gender \& Society, 17(3), 342-366.

Martin, P. Y. (2006). Practising gender at work: Further thoughts on reflexivity. Gender, Work and Organization, 13(3), 254-276. 
Mavin, S., \& Grandy, G. (2011). Doing Gender Well and Differently in Dirty Work: The Case of Exotic Dancing. Gender, Work \& Organization, online early.

McDonald, J. (2012). Conforming to and Resisting Dominant Gender Norms: How Male and Female Nursing Students Do and Undo Gender. Gender, Work \& Organization, online early.

McIlvenny, P. (Ed.). (2002). Talking gender and sexuality. Amsterdam: John Benjamins.

MacInnes, J. (1998) The End of Masculinity. Buckingham: Open University Press.

Metcalfe, B. \& Linstead, A. (2003). Gendering Teamwork: Re-Writing the Feminine. Gender, Work and Organization, 10(1), 94-119.

Murray, S. B. (1996). "We all love Charles" Men in child care and the social construction of gender. Gender \& Society, 10(4), 368-385.

Nentwich, J. C. (2008). New fathers and mothers as gender trouble makers? Exploring discursive constructions of heterosexual parenthood and their subversive potential. Feminism and Psychology, 18(2), 207-230.

Pierce, J. L. (1995). Gender trials: emotional lives in contemporary law firms. Berkeley: University of California Press.

Pierce, J. L. (1996). Rambo litigators: Emotional labor in a male-dominated occupation. In Cheng, Cliff. Thousand Oaks: Sage.

Pilgeram, R. (2007). "Ass-kicking" Women: Doing and Undoing Gender in a US Livestock Auction. Gender, Work \& Organization, 14(6), 572-595.

Poggio, B. (2006). Editorial: Outline of a theory of gender practices. Gender, Work and Organization, 13(3), 225-233.

Powell, A., Bagilhole, B. \& Dainty, A. (2008). How women engineers do and undo gender: Consequences for gender equality. Gender, Work and Organization, Online Early.

Pullen, A., \& Simpson, R. (2009). Managing Difference in Feminized Work: Mens Otherness and Social Practice. Human Relations, 62(4), 561-587. 
Ridgeway, C. L. (1997). Interaction and the conservation of gender inequality: Considering employment. American Sociological Review(62), 218-235.

Tyler, M. \& Abbott, P. (1998). Chocs away: Weight watching in the contemporary airline industry. Sociology, 32(3), 433-450.

West, C. \& Zimmerman, D. H. (1987). Doing Gender. Gender \& Society, 1(2), 125-151.

West, C., \& Zimmerman, D. (2009). Accounting for Doing Gender. Gender \& Society, 23, $112-122$.

Wickes, R., \& Emmison, M. (2007). They are all “doing gender" but are they are all passing? A case study of the appropriation of a sociological concept. The Sociological Review, $55(2), 311-330$.

Williams, C. L. (1989). Gender differences at work: Women and men in nontraditional occupations. Berkley: California University Press.

Williams, C. L. (1995). Still a man's world : men who do "women's work". Berkeley: University of California Press.

Williams, C. L. (Ed.). (1993). Doing "women's work" : men in nontraditional occupations. London: Sage. 